\title{
Education Funding and Individual Preferences for Redistribution
}

\author{
Marius R. Busemeyer
}

\begin{abstract}
The analysis of the association between welfare state institutions and individual-level attitudes has become an important research topic in the past years. This article focuses on the association between the institutional set-up of the education system, the division of labour between public and private sources in funding human capital formation, and preferences for redistribution. Applying a multilevel research design with International Social Survey Programme (ISSP) survey data for 20 OECD countries, the main empirical finding of this article is that individuals in countries with high levels of private spending on education are less willing to support government-induced redistribution. One possible interpretation of this finding is that the specific kind of education financing influences the prevailing norms of social solidarity and expectations vis-à-vis the state.
\end{abstract}

\section{Introduction}

Studying the association between macro level institutions such as the welfare state and individual level social policy preferences has become an important field of research during the past decade. Following the initial work of Pierson (1994) and Rothstein (1998), the guiding research question is how institutions and policies create feedback effects on the level of individual preferences and attitudes. A shortcoming of this literature is that it often uses broad regime categories or prevailing ideologies to determine the effects of the macro level on the micro level [see Jaeger (2006) and Jakobsen (2010) for a similar critique]. This might result in an underestimation of the effect of particular aspects of welfare state institutions and a lack of sound theoretical underpinnings in terms of the causal mechanisms at work. What has received less attention in general is the institutional set up of the education system and its implications for the formation of welfare state attitudes on the level of individuals. More specifically, the core argument of this article is that the prevailing division of labour in education financing shapes individual level preferences towards redistribution. When a large share of education spending comes from private sources, individual support for redistribution is depressed. This finding can be interpreted in different ways. From a culturalist perspective (Pfau Effinger, 2005; Van
Oorschot et al., 2008), institutions are expected to be related to prevailing perceptions of the role of the individual vis à vis the state. This perspective is con trasted with a self interest based explanation.

\section{Literature Review}

In recent years, the study of individual preferences on redistribution has become a booming field of scholarship in comparative welfare state research. One strand within this literature has mainly been concerned with identify ing the micro level determinants of social policy prefer ences, for example partisan ideology or self interest as determined by the individual position in the economy and the transfer classes of the welfare state (Hasenfeld and Rafferty, 1989; Kangas, 1997; Alesina et al., 2001; Iversen and Soskice, 2001; Alesina and Angeletos, 2005; Alesina and La Ferrara, 2005; Cusack et al., 2006; Lynch and Myrskyla, 2009). More recently, scholars explored the impact of culture and norms on issues such as perceptions of 'deservingness' of recipients of welfare state benefits (Van Oorschot, 2006), the role of religious orientations (Scheve and Stasavage, 2006; De La O and Rodden, 2008), and individual beliefs on the relative importance of luck as a determinant of economic success on support for redistribution (Alesina et al., 2001; Fong, 2001; Corneo and Gruner, 2002; Linos and West, 2003; 
Alesina and Angeletos, 2005; Alesina and La Ferrara, 2005).

Much less well understood is the impact of institu tional and cultural macro contexts on the dynamics on the micro level, although interest in this particular area of research has increased significantly. Most of the studies are concerned with the question whether the institutional set up of the welfare state has an impact on individual level support for social policies (Papadakis, 1993; Svallfors, 1997, 2004, 2010; Bean and Papadakis, 1998; Andreß and Heien, 2001; Arts and Gelissen, 2001; Blekesaune and Quadagno, 2003; Linos and West, 2003; Lipsmeyer and Nordstrom, 2003; Jaeger, 2006, 2009; Jakobsen, 2010). So far, the evidence is mixed, suggesting that the character of a welfare state regime does not have a systematic impact on the individual level, although recent work by Jaeger produces more robust results supporting the notion that support for the welfare state is stronger in the Scandinavian countries (Jaeger, 2009). Also, the literature is divided on the issue whether individual social policy preferences should be regarded as a causal factor explaining the resilience of welfare states against retrenchment (Brooks and Manza, 2006, 2007; Rehm, 2011) or whether, vice versa, the institutions of the welfare state are the primary causal factor shaping patterns of individual support and opposition (Ken worthy, 2009; Svallfors, 2010).

Another strand of literature is work in comparative public policy and comparative political science that has been concerned with identifying the political and insti tutional determinants of policy output, i.e. education spending (Busemeyer, 2007, 2009; Schmidt, 2007; Ansell, 2008, 2010; Jensen, 2011). Most of this literature aims at explaining variation in public education spending, but Wolf (2009) as well as Wolf and Zohlnhofer (2009) are concerned with levels of private education spending, emphasizing the role of partisan politics and the constitutional structure of political systems as explana tory variables in causing variation across countries. The blind spot of this literature is that it is not concerned with the feedback effects of policy output on preferences and attitudes. Thus, bringing together the two literatures in comparative public policy on education spending and welfare state research on attitudes, this article aims at contributing to develop a deeper understanding of the connections, complementarities, and feedback effects between the education system, the welfare state regime at large, and the micro level of preferences and attitudes.

\section{Theory and Hypotheses}

Education systems may vary along a large number of dimensions, e.g. the relative emphasis put on academic versus vocational education or the general level of public investment in human capital formation (Busemeyer and Nikolai, 2010). For the purpose of this article, I will focus on a particular dimension of variation: the division of labour between public and private sources in the financing of education (later in the text, I explain more fully why and how this dimension matters). Education systems in advanced industrial democracies differ significantly in this respect (see Figure 1): In the Scandinavian countries, but also in countries such as Ireland and Switzerland, almost all of the money spent on educational institutions (school, universities, etc.) come from public sources. In contrast, the share of private sources in education spending is particularly high in the Anglo Saxon countries (but not Ireland) and Japan. According to the OECD (2009: 224) definition, private sources of spending include spending from private households (students and their families) and other private entities (charitable organizations, business investing in appren ticeship training, etc.). In most countries, the share of private household spending in private education spending dominates, in particular, in higher education, except for countries such as Germany, where firms contribute a relative large part of private education spending, as employers' contributions to the firm based apprenticeship training system are counted in this category (Wolf, 2009: 51).

Patterns of cost sharing between public and private sources are not completely determined by differences in enrolment in public and private educational institu tions. In Japan, for example, public universities charge high tuition fees (Heidenheimer, 1997), although there is a substantial amount of private higher education institutions as well. In contrast, education reforms in Sweden in the 1990s have led to a steep increase in the number of private ('independent') schools, but the share of public sources in education spending remains stable at around 90 per cent because these independent schools are financed by the state (Klitgaard, 2008). With regard to preferences for redistribution, however, it can be argued that the distribution of real costs of human capital acquisition matters more than enrolment as such.

In the following, I am going to develop hypotheses on how and why differences in the financing of education matter. The issue can be approached from two different perspectives: the first emphasizes self interest as the basic determinant of welfare state preferences, whereas the second is more sensitive towards norms and culture.

Coming back to the first point, an influential strand in the literature on welfare state attitudes argues that 
= Private Share in Education Spending, all levels of education

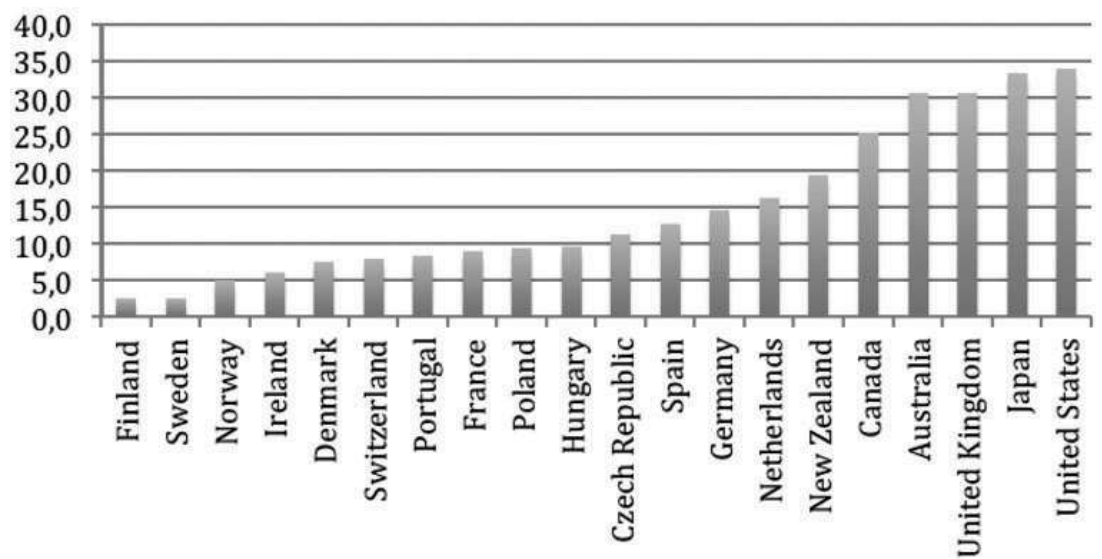

Figure 1 Share of education funding from private sources in OECD countries, 2007. Source: OECD, 2010: Education at a Glance, 231. Note: Data for Ireland, Norway, and Switzerland are from earlier years (2006 in the case of Ireland, 2000 in the other cases)

individual policy preferences are largely conditioned by self interest, i.e. the individual's position on the income scale, her status as beneficiary of or contributor to welfare state services, or her employment status more generally. Ultimately, individual status on the labour market depends on the income of the individual and, as is argued in human capital theory (Becker, 1993), on the individual's human capital endowment. The link be tween skills and social policy preferences has long been recognized in the literature. For example, Iversen and Soskice (2001) famously argue that workers with more specific types of human capital have a higher demand for redistribution and generous social policies to protect their specific skill investments (see also Estévez Abe et al., 2001; Cusack et al., 2006). Rehm $(2009,2011)$ adds to this literature by showing that individual demand for redistribution is also influenced by the specific risk profile of a given skill endowment.

Extending this line of thought, one could argue that individual demand for redistribution is also determined by how individuals acquire their human capital. Of crucial importance here is the division of labour between public and private sources in the financing of education. A large share of private sources in education funding has consequences for the formation of preferences on redistribution. Individuals who have paid for a signifi cant share of their human capital endowment out of their own pockets are expected to be more opposed to redistribution than individuals living in education systems with a high share of public sources in education funding. This is because high levels of redistribution depress the wage premium of skill investments and make it harder for individuals to recoup their skill investments. Thus, out of self interest, individuals in countries with a high level of private education spending oppose govern ment intervention with the aim of redistribution. Vice versa, individuals whose education is largely financed with public money are more supportive of government involvement and redistribution, as they have benefitted from it before.

Above and beyond self interest, the institutional set up of the education system might also shape under lying cultural norms and values as well as general expectations with regard to the relationship between education and redistributive social policies. Institutions not only shape actor's strategies, preferences, and choices but also the prevailing welfare state culture. Following recent work on the complex relationship between culture, welfare state policies, and attitudes (Jo, 2011; Pfau Effinger, 2005; Van Oorschot et al., 2008), the impact of culture should not be conceptualized as something so abstract that it both explains everything and nothing. Instead, it seems more fruitful to think about the impact of culture as the effects of institutions on the intermediate level of 'societal values' (Jo, 2011), defining specific 'logics of appropriateness' (March and Olsen, 1989) and perceptions of 'deservingness' (Van Oorschot, 2006). Also, in contrast to the literature on welfare regimes and attitudes (see earlier in the text), I propose to focus on the role of specific institutions instead of abstract regime categories, which under estimate the heterogeneity of welfare state regimes 
[see Jaeger (2006) and Jakobsen (2010) for a similar argument].

More concretely, building on Rothstein (1998), it could be argued that the universal provision of social services such as education by the state also increases societal support for the universal welfare state model, as individuals come to benefit from public services and develop concurrent expectations with regard to the role of the state. In contrast, a high level of private spending in education might go along with a general culture of promoting individual responsibility in social and educa tion policy, i.e. a lower willingness to support government induced redistribution.

Data limitations (see next section for details) only allow to test the self interest versus the cultural thesis in an indirect manner. What would be needed is data on how much individuals themselves had to pay for their education. This issue could be addressed in future research, using survey data for individual countries such as the United States. For the present article, I have to rely on aggregate data on the share of private spending on education (see Figure 1). If the self interest hypoth esis would be the dominant mechanism, I would expect a significant cross level interaction between the size of the individual stock of human capital and the private spending share on the aggregate level. That is the (negative) micro level effect of educational background on support for redistribution would be even more pronounced in countries with a higher share of private education spending. In contrast, the culturalist hypoth esis would receive support if the country level variable does not have a modifying effect on the impact of educational background on the micro level. In that case, the predominance of private education funding on the country level would mostly affect the overall level of support for redistribution.

At this point, a final word needs to be said on the issue of causality. As said earlier in the text, there is considerable debate in the literature as to whether causality runs from preferences to policies and institu tions (Brooks and Manza, 2006, 2007; Rehm, 2011) or vice versa (Kenworthy, 2009). In my view, it is moot to try to identify a prime causal factor. Instead, the feedback effects between attitudes on the micro level and institutions on the macro level jointly contribute to the emergence and stabilization of development paths over time. Quantitative analysis of the kind used in this article can only identify correlations at a particular moment in time. Hence, they should and need to be complemented with historical studies tracing the se quential development of feedback effects and their contribution to the formation of different and distinct welfare state regimes.

\section{Data, Control Variables, and Methods}

Our primary data source is the International Social Survey Programme (ISSP) 'Role of Government IV' data set from 2006. Here, respondents are asked:

'On the whole, do you think it should or should not be the government's responsibility to... reduce income differences between the rich and the poor'.

Four answer categories are provided (Definitely should be, probably should be, probably should not be, definitely should not be). Indecisive answers are deleted from the sample. For the main part of the empirical analysis, these have been collapsed into two categories (support or opposition to government induced redistri bution). There are several reasons for this: First, the results of the regression analysis are much easier to interpret and handle when the dependent variable is binary. Second, it seems reasonable to assume that respondents will draw a sharp line between general support and opposition to the statement, but not necessarily between strong and moderate levels of support or opposition, respectively. A further pragmatic reason is that the statistical software used for this article (STATA 12.1) to calculate random effects multilevel models is much better developed in the case of simple logit models compared with ordered or generalized ordered logit models. However, I will also display the results of a generalized ordered logit model specification to demonstrate the robustness of the findings.

The 20 countries covered in this data set, for which we have data on the main independent variables on the macro level, are as follows: Australia, Canada, the Czech Republic, Denmark, Finland, France, Germany, Great Britain, Hungary, Ireland, Japan, the Netherlands, New Zealand, Norway, Poland, Portugal, Spain, Sweden, Switzerland, and the United States.

In the micro level analysis, I use a common set of standard control variables, such as education, income, gender, age, and labour market status. Education is simply operationalized as years of schooling. It is thus a good indicator of the accumulated individual stock of human capital. Similar to income (given in income deciles), it is expected to be negatively associated with support for redistribution. Women are usually found to be more supportive of redistribution (see Finseraas, 2009). Age is expected to be positively associated with support for redistribution as individuals move from the educational phase to the employment phase, when the demand for insurance via social policy increases (Moene and Wallerstein, 2001, 2003). However, support for redistribution might decline again in the later stages of 
the lifecycle (Busemeyer et al., 2009). Therefore, I include age and its squared term in the regressions. Finally, employment status, though correlated with some of the other control variables, is included in categorical form as well. I distinguish between full time employment (base category), part time employment, being voluntary out of the labour force, unemployed, student/in educa tion, and retired. Including additional micro level con trol variables such as union membership and ideological orientation (self placement on the left right scale) is problematic because they might be endogenous (i.e. individuals supporting redistribution are more likely to be union members and vice versa). Furthermore, indi viduals are reluctant to reveal their partisan preferences, which results in a significant decrease in the number of individual observations (by more than 30 per cent in our case, see below Table 1). Nevertheless, I present a model specification including ideological self placement and union membership to show the robustness of the main findings.

The most important macro level variable is the division of labour between public and private sources in education funding. The OECD provides data on this in its 'Education at a Glance' series. I include data for the year 2006, when most of the fieldwork for the survey was conducted. I use two different specifications, reflecting a narrow and a broad conception of private investments in education. The first indicator includes 'tuition fees and other student or household payments to educational institutions, minus support provided through public subsidies' (OECD, 2009: 224). It does not include private spending that is related to the acquisition of education, which is not directed at educational institutions (such as students' living ex penses and foregone earnings). In the second broader definition, private spending by 'other private entities' such as firms and foundations is included in addition to household spending. Conceptually, the first measure might be preferred. However, there is the problem of missing data for Finland, Germany, Hungary, and Switzerland (I use data for private spending including other private entities for these countries as a proxy). I use data for all levels of education because this better captures the general division of labour between public and private sources in the education system as a whole. Furthermore, countries might differ with regard to the allocation of similar education and training programmes to different educational levels. This problem is avoided by looking at the private share of spending for all levels of education instead of individual levels.

The second variable on the macro level is the level of inequality. As is argued by Finseraas (2009), high levels of inequality should increase overall demand for redistribution. This hypothesis is based on the model developed by Meltzer and Richard (1981), according to which an increase in inequality leads to a decline in the relative position of the median voter, i.e. more people have an income below the level of the average, not the median income. Hence, popular support for redistribu tion increases. An additional reason for including levels of inequality on the macro level is that the survey questions used in this study (in particular, the first one) do not take into account differences in the status quo across countries. The data on inequality are taken from the Standardized World Income Inequality Database (Solt, 2009). This data set is based on the inequality data from the Luxembourg Income Study, but standardized and interpolated to create continuous time series. The Luxembourg Income Study data measure inequalities in the distribution of wealth across households and calcu lates a Gini index, ranging from 0 (total equality in the distribution of wealth) to 100 (total inequality, i.e. one individual owns everything). Empirical values for countries are in the range of 2040 . I use the data for net (i.e. post tax) income inequality.

To demonstrate the robustness of the findings, I use a number of additional control variables. Given the small number of cases, this is not unproblematic. Also, some of the independent variables are correlated (e.g. the private share in education funding is correlated with income inequality at a level of 0.56 ). From a methods point of view, there is a trade off between the problems of multicollinearity and omitted variable bias when deciding whether to include both variables. As a consequence, different model specifications will be analysed. Additional control variables on the macro level are levels of public education and social spending as percentage of GDP, net union density, and a measure of the cumulative cabinet share of leftist parties (1990 2006). The expectation is that higher levels of all these variables are associated with more support for redistribution, as this indicates a politically supportive climate for welfare state expansion. I also include national income per capita as a measure of economic well being. Data are taken from the OECD Education Statistics database, the Comparative Political Data set (Armingeon et al., 2010), and the OECD Factbook.

I use multilevel logit random effects models with country as the grouping variable (random intercept models). To test the culturalist hypothesis, the macro level variables are included in the model as independent variables because the theory predicts a direct effect on preferences for redistribution. The self interest hypothesis is operationalized in the form of a cross level interaction, e.g. an interactive term between education on the micro level and the private 
Table 1 Determ nants of nd v dua support for red str but on

Dependent variable

(1)

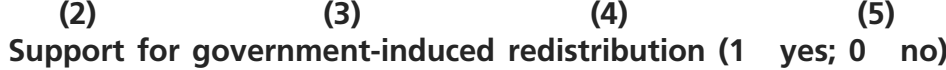

(4)

\begin{tabular}{|c|c|c|c|c|c|c|c|c|c|c|c|c|}
\hline \multicolumn{13}{|l|}{ Micro level } \\
\hline Income & $0.184^{* * *}$ & $(0.0093)$ & $0.184^{\star \star \star}$ & $(0.0093)$ & $0.184^{* * *}$ & $(0.0093)$ & $0.185^{* * *}$ & $(0.0093)$ & $0.185^{\star * \star}$ & $(0.0094)$ & $0.171^{* * *}$ & $(0.0114)$ \\
\hline Female & $0.142^{* * *}$ & $(0.0357)$ & $0.142^{\star * \star}$ & $(0.0357)$ & $0.141^{\star * *}$ & $(0.0357)$ & $0.142^{\star * *}$ & $(0.0357)$ & $0.142^{\star * *}$ & $(0.0357)$ & $0.0780^{*}$ & $(0.0438)$ \\
\hline Education & $0.0417^{* * *}$ & $(0.0049)$ & $0.0419^{* * *}$ & $(0.0049)$ & $0.0483^{* * *}$ & $(0.0085)$ & $0.0497^{* * *}$ & $(0.0086)$ & $0.0482^{* * *}$ & $(0.0085)$ & $0.0419^{* * *}$ & $(0.0059)$ \\
\hline Age & $0.0150^{\star *}$ & $(0.0067)$ & $0.0149^{* *}$ & $(0.0067)$ & $0.0149^{* *}$ & $(0.0067)$ & $0.0147^{* *}$ & $(0.0067)$ & $0.0149^{* *}$ & $(0.0067)$ & 0.0012 & $(0.0086)$ \\
\hline Age squared & $8.60 \mathrm{e}-05$ & $(6.98 \mathrm{e}-05)$ & $8.51 \mathrm{e}-05$ & $(6.98 \mathrm{e}-05)$ & $8.38 \mathrm{e}-05$ & $(6.99 \mathrm{e}-05)$ & $8.23 \mathrm{e}-05$ & $(6.99 \mathrm{e}-05)$ & $8.37 \mathrm{e}-05$ & $(6.99 \mathrm{e}-05)$ & $6.75 \mathrm{e}-05$ & $(9.05 e-05)$ \\
\hline Part-time employed & 0.0115 & $(0.0603)$ & 0.0119 & $(0.0603)$ & 0.0132 & $(0.0603)$ & 0.0137 & $(0.0603)$ & 0.0124 & $(0.0603)$ & 0.0812 & $(0.0725)$ \\
\hline Not in labour force & 0.0692 & $(0.0628)$ & 0.0689 & $(0.0628)$ & 0.0695 & $(0.0628)$ & 0.0695 & $(0.0628)$ & 0.0708 & $(0.0629)$ & 0.0412 & $(0.0826)$ \\
\hline Unemployed & $0.514^{* * *}$ & $(0.114)$ & $0.516^{* * *}$ & $(0.114)$ & $0.514^{\star * *}$ & $(0.114)$ & $0.517^{* * *}$ & $(0.114)$ & $0.515^{* * *}$ & $(0.114)$ & $0.521^{* \star *}$ & $(0.154)$ \\
\hline In education & $0.407^{* * *}$ & $(0.118)$ & $0.408^{* * *}$ & $(0.118)$ & $0.411^{\star * *}$ & $(0.118)$ & $0.414^{* * *}$ & $(0.118)$ & $0.407^{* * *}$ & $(0.118)$ & $0.375^{* *}$ & $(0.149)$ \\
\hline Retired & 0.0010 & $(0.0699)$ & 0.0015 & $(0.0699)$ & 0.0032 & $(0.0701)$ & 0.0029 & $(0.0701)$ & 0.0049 & $(0.0702)$ & 0.0253 & $(0.0878)$ \\
\hline $\begin{array}{l}\text { Left-right self-placement } \\
\quad \text { (positive values = right wing) }\end{array}$ & & & & & & & & & & & $0.636^{* * *}$ & $(0.0244)$ \\
\hline Union member & & & & & & & & & & & $0.360^{* * *}$ & $(0.0543)$ \\
\hline \multicolumn{13}{|l|}{ Macro level } \\
\hline Private share in education funding & $0.0561^{* * *}$ & $(0.0122)$ & & & $0.0622^{* * *}$ & $(0.0138)$ & & & & & $0.0479^{* * *}$ & $(0.0145)$ \\
\hline $\begin{array}{l}\text { Private share in education } \\
\text { funding (only households) }\end{array}$ & & & $0.0820^{* \star \star}$ & $(0.0200)$ & & & $0.0917^{\star * *}$ & $(0.0220)$ & & & & \\
\hline $\begin{array}{l}\text { Interaction: private share } \\
\times \text { education }\end{array}$ & & & & & 0.000470 & $(0.000495)$ & & & 0.000462 & $(0.000496)$ & & \\
\hline $\begin{array}{l}\text { Interaction: private share } \\
\quad(\text { only households }) \times \text { education }\end{array}$ & & & & & & & 0.000753 & $(0.000692)$ & & & & \\
\hline Socio-economic inequality (Gini) & $0.111^{* * *}$ & $(0.0288)$ & $0.112^{* * *}$ & $(0.0315)$ & $0.110^{* * *}$ & $(0.0288)$ & $0.112^{* * *}$ & $(0.0315)$ & & & $0.0928^{* * *}$ & $(0.0307)$ \\
\hline National income per capita & & & & & & & & & & & $1.12 \mathrm{e}-05$ & $(1.07 \mathrm{e}-05)$ \\
\hline $\begin{array}{l}\text { Public education spending } \\
\text { as } \% \text { of GDP }\end{array}$ & & & & & & & & & & & -0.145 & $(0.156)$ \\
\hline Public social spending as $\%$ of GDP & & & & & & & & & & & 0.0030 & $(0.0319)$ \\
\hline Constant & 0.936 & $(0.795)$ & 0.927 & $(0.849)$ & 0.833 & $(0.802)$ & 0.805 & $(0.857)$ & $1.194^{* * *}$ & $(0.195)$ & 1.898 & $(1.456)$ \\
\hline \multicolumn{13}{|l|}{ Variance components } \\
\hline $\begin{array}{l}\text { Level } 2 \text { intercept standard } \\
\text { deviation (Standard error) }\end{array}$ & 0.4001 & $(0.0662)$ & 0.4251 & $(0.0702)$ & 0.3998 & $(0.0661)$ & 0.4253 & $(0.0702)$ & & & 0.3861 & $(0.0654)$ \\
\hline $\begin{array}{l}\text { Intra-class correlation (Rho) } \\
\text { (Standard error) }\end{array}$ & 0.0464 & $(0.0146)$ & 0.0521 & $(0.0163)$ & 0.0463 & $(0.0146)$ & 0.0521 & $(0.0163)$ & & & 0.0433 & $(0.0141)$ \\
\hline Log likelihood & $10,717.66$ & & $10,718.86$ & & $10,717.21$ & & $10,718.27$ & & $10,674.46$ & & $7,123.95$ & \\
\hline Country dummies & No & & No & & No & & No & & Yes & & No & \\
\hline Observations & 19,352 & & 19,352 & & 19,352 & & 19,352 & & 19,352 & & 13,085 & \\
\hline Number of countries & 20 & & 20 & & 20 & & 20 & & 20 & & 20 & \\
\hline
\end{tabular}

Note: Standard errors in parentheses.

${ }^{*} P<0.1,{ }^{* * P}<00.05,{ }^{* * *} P<0.01$. 
share of spending on the macro level. Given the categorical nature of the dependent variable, an ordered logit model specification would be a plausible alternative. However, a Brant test indicated that the assumption of proportional odds is violated. Therefore, a generalized ordered logit model with country clustered standard errors is computed instead, which, however, does not fully take into account random effects and the multilevel structure of the data.

A problem in the research design is that the number of level 2 units (countries) is limited (20). A low number of countries in multilevel research designs severely reduces the statistical power available for detecting significant effects on the macro level. Unfortunately, there is no easy remedy to this problem. The 2006 wave of the ISSP survey includes more countries than the earlier waves. My sample includes all countries (developed democracies) from the ISSP, for which data on the private share of education spending were available. Furthermore, the low number of countries biases the analysis against finding significant effects. Thus, I cannot say for sure whether non significant effects in fact become significant in a larger sample of countries, but in case I do find significant effects, these should be robust in a larger set of cases as well.

\section{Results}

Table 1 displays the core findings of the article. First, some comments on the micro level predictors, which perform largely as expected. Income and education are negatively associated with individual support for redis tribution, whereas being female or unemployed has a positive impact. Individuals in education are less likely to support redistribution, and age has a positive impact on support, although this effect is not particularly strong in terms of statistical significance. Compared with the socio economic variables, the political variables have a strong and statistically significant impact. Being a union member increases support for redistribution. Self identification with the political right has a negative impact as could be expected. Similar effects can be found for the generalized ordered logit model (Table 3).

Our main variable of interest, the private share in education funding, has a robust and statistically signifi cant impact on individual level support for redistribu tion across all model specifications. The size of the coefficient estimate of the comprehensive private spend ing variable remains fairly stable across specifications, varying between 0.05 and 0.06 . The coefficient's magni tude is reduced somewhat in model 6 , when the partly endogenous variables of partisan identification and union membership are included. ${ }^{2}$ In models 2 and 4 , I use the narrower operationalization (private spending by households only). Again, the effect is negative and highly significant. In models 3,4 , and 5 , I include a cross level interaction between educational background and private spending share (both the broader and the narrow definition). In model 5, I drop all macro level variables and include country dummy variables instead. The interactive terms does not reach conventional levels of statistical significance in any of these specifications. The interpretation of this finding is that the culturalist hypothesis receives more empirical support than the self interest based hypothesis.

Model 6 includes additional control variables on the micro and the macro level. Besides our main variable of interest, inequality is the only other macro variable that has a robust effect on redistributive preferences. As expected, the effect is positive, i.e. higher levels of inequality trigger an increase in the individual support for redistribution (confirming Finseraas, 2009). Because of the low number of cases, multicollinearity between the macro level variables might hide significant associations. Therefore, I perform an additional analysis, adding macro level variables sequentially (see Table 2). Still, none of them are significant, whereas the effects of

Table 2 Additional robustness tests, macro-level variables

Independent variable

(1)
(2)
(3)
(5)

\begin{tabular}{|c|c|c|c|c|c|c|c|c|c|c|}
\hline Private share of education funding & $0.0665^{\star * *}$ & $(0.0148)$ & $0.0599^{* * *}$ & $(0.0148)$ & $0.0586^{* * *}$ & $(0.0136)$ & $0.0650^{* * *}$ & $(0.0139)$ & $0.0544^{\star * *}$ & $(0.0134)$ \\
\hline Socio-economic inequality (Gini) & $0.107^{* * *}$ & $(0.0287)$ & $0.114^{* * *}$ & $(0.0300)$ & $0.102^{* * *}$ & $(0.0282)$ & $0.100^{* * *}$ & $(0.0302)$ & $0.0941^{* * *}$ & $(0.0269)$ \\
\hline Public education spending as $\%$ of GDP & 0.103 & $(0.140)$ & & & & & & & & \\
\hline Public social spending as $\%$ of GDP & & & 0.0120 & $(0.0298)$ & & & & & & \\
\hline National income per capita & & & & & $1.36 \mathrm{e}-05$ & $(9.96 \mathrm{e}-06)$ & & & & \\
\hline Net union density & & & & & & & 0.0051 & $(0.0054)$ & & \\
\hline $\begin{array}{l}\text { Cumulative cabinet share of } \\
\text { left parties (1990-2006) }\end{array}$ & & & & & & & & & 0.00046 & $(0.004$ \\
\hline
\end{tabular}

Note: These models also include the same micro-level control variables as in the models of Table 1. To improve readability, these are not displayed here. ${ }_{* * *} P<0.01$ 
private spending share and inequality remain significant and robust.

Using model 3 from Table 1, I calculate predicted probabilities, which are displayed graphically in Figure 2. ${ }^{3}$ Holding the other variables at their mean value and using the encompassing measure of private spending share, individual level support for redistribu tion decreases from about 81 per cent to 58 per cent, when the share of private spending increases from 2 per cent (the level of Finland) to 25 per cent (the level of the United Kingdom). ${ }^{4}$ Using the narrow definition of private spending share (model 4), the equivalent pre dicted change in individual level support for redistribu tion is a reduction from 84 per cent (with the level of private spending of Sweden) to 56 per cent (at the US level of private household spending).

The results from the generalized ordered logit model lend further support to the main findings (see Table 3 ). The private share in education funding has a robust and statistically significant negative effect on individual level support for redistribution. This distinguishes it from all the other control variables on the macro level, which do not produce robust associations. The magnitude of the coefficient estimate is reduced somewhat in the case of the third cut off point (definitely should be government responsibility vs. less support).

The results are presented graphically in Figure 3 because the magnitude of the effects cannot be directly read off from the coefficients in Table 3. I calculate predicted probabilities for the different response cate gories, varying the main variable of interest (private spending share) and holding the other variables at their mean (the dummy variables are set at zero). I focus on the highest response category and the lowest to keep the figure readable. The upper solid line represents the predicted probability of definitely supporting government induced redistribution ( $\mathrm{Y}$ 4), whereas the dashed line represents the opposite case: definitely no support for redistribution ( $\mathrm{Y}$ 1). The solid line exhibits a strong downward slope, i.e. support for redistribution declines for higher levels of private education spending. The dashed line has a positive slope, indicating an increase in opposition against redistribution when the share of private education spending is high.

\section{Discussion and Conclusions}

This article aims at developing a new perspective on the study of popular attitudes towards government induced redistribution. By highlighting the connections between redistributive attitudes and the education system, I also want to promote the reintegration of the study of education into comparative welfare state research (see Allmendinger and Leibfried, 2003; Iversen and Stephens, 2008; Busemeyer and Nikolai, 2010, for a similar proposal).

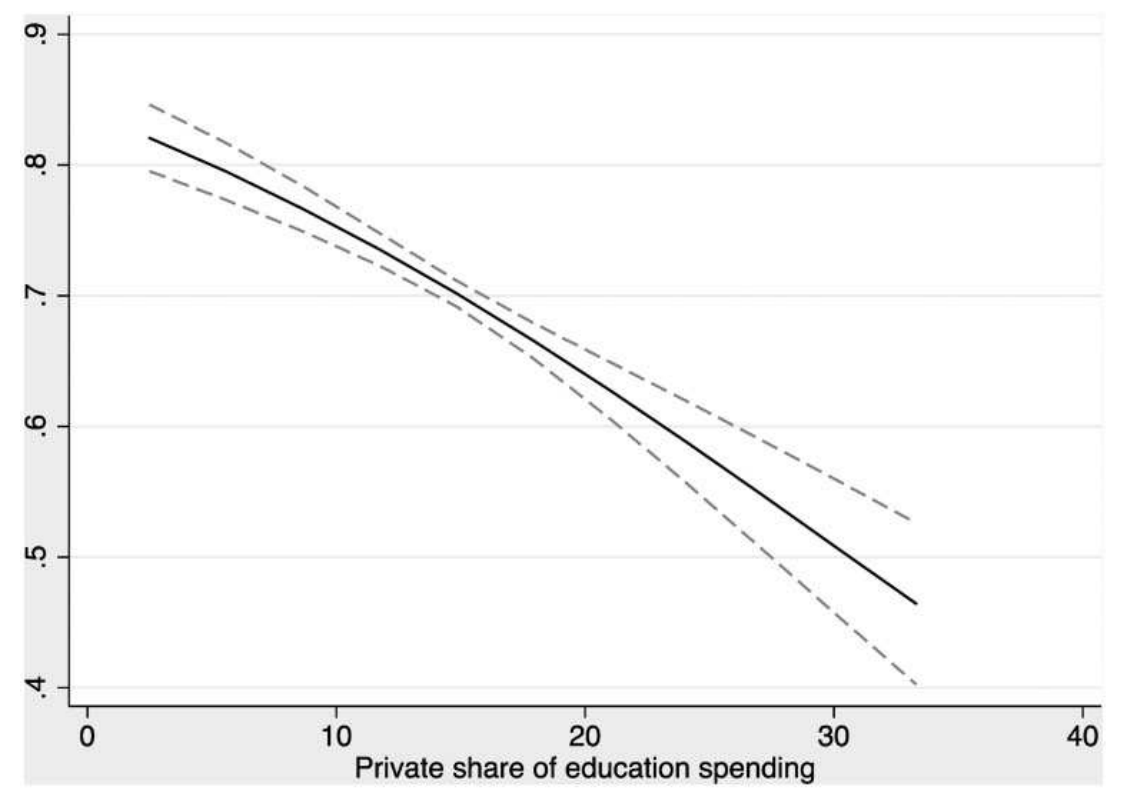

Figure 2 Predicted probability of supporting government induced redistribution. Note: Calculation is based on model 3, Table 1. Dashed lines represent 95\% confidence intervals. 
Table 3 Generalized ordered logit model with country-clustered standard errors

Should it be the government's responsibility to reduce income differences between the rich and the poor?

\section{More support versus definitely should not be}

\section{Definitely/probably should be versus definitely/probably should not be}

\section{Income}

Female

Education

Age

Age square

Part time employed

Not in labour force

Unemployed

In education

Retired

Private share in education funding Socio economic inequality (Gini)

National income per capita

Public education spending, \% of GDP

Public social spending, $\%$ of GDP

Constant

Pseudo $R^{2}$

Observations

$\begin{array}{ll}0.162^{\star * \star} & (0.0283) \\ 0.243^{\star \star *} & (0.0684) \\ 0.0422^{\star * *} & (0.0105) \\ 0.0163 & (0.0106) \\ 0.0002^{\star *} & (9.30 \mathrm{e} 05) \\ 0.124 & (0.134) \\ 0.168 & (0.137) \\ 0.371^{\star *} & (0.188) \\ 0.617^{\star *} & (0.246) \\ 0.169 & (0.118) \\ 0.0503^{\star * *} & (0.0143) \\ 0.0494 & (0.0476) \\ 4.99 \mathrm{e} 06 & (1.41 \mathrm{e} 05) \\ 0.234^{\star *} & (0.118) \\ 0.0036 & (0.0298) \\ 3.783 & (2.509) \\ 0.0457 & \\ 19,352 & \end{array}$

$0.169^{* * *}$

$0.114^{* *}$

$0.0354^{* * *}(0.0081)$

$0.0148^{* *}(0.0072)$

$9.49 \mathrm{e} 05$

0.0049

0.0332

$0.420^{* * *}$

$0.451^{\star * *}$

0.0183

$0.0499^{* * *}$

(6.90e 05)

(0.115)

(0.119)

(0.121)

(0.174)

(0.109)

(0.0101)

$0.0796^{* *}$

(0.0394)

3.35 e 06

0.162

0.0106

0.458

(1.31e 05)

(0.151)

(0.0343)

(2.272)

19,352

Definitely should

be versus

less support

${ }^{* *} P<0.05,{ }^{* * *} P<0.01$

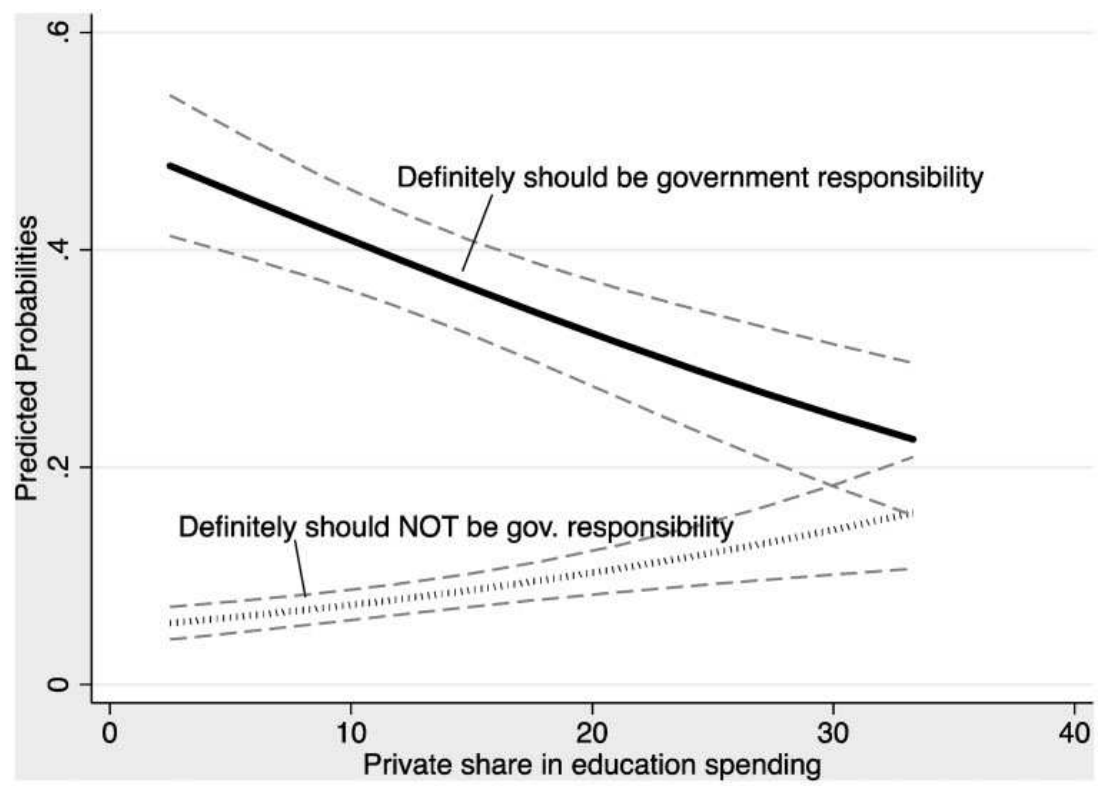

Figure 3 Predicted probabilities for different levels of private share in education spending. 
The main empirical finding of the article is to show that the institutional set up of the education system, in particular the division of labour between public and private sources in funding human capital investment, is associated with individual support for redistribution. In countries with a high share of private education financing, individual support for redistribution is sig nificantly lower and, vice versa, a high public share is associated with strong individual level support. This finding can be interpreted in different ways. I argued that the empirical analysis lends preliminary support for a culturalist interpretation of this association. The division of labour in education financing influences the general level of support for redistribution in a given country, but there is no evidence that it mitigates the micro level impact of educational background on redis tributive preferences, which would be supportive of a self interest based argument. Hence, the kind of educa tion financing likely contributes to the formation of specific norms of solidarity and expectations with regard to the legitimate role of the state as an agent of redistribution and provider of social services. However, our measure for the stock of human capital (years of education) is crude. More and better data on the individual level (e.g. the actual level of investments in human capital formation) would be needed to really test the self interest based argument. Thus, the conclusion of this article is necessarily preliminary, and the empirical findings can be interpreted in different ways.

\section{Funding}

The project was partly supported by funding from the German Research Foundation (DFG), Grant No. BU $1852 / 41$.

\section{Notes}

1 The ISSP 'Role of Government' data set also includes a set of questions on individual preferences for particular kinds of social spending, which could be taken as indicators of redistributive preferences. I decided against using the measures for spending preferences because they are more concretely focused on various policy fields and the issue of public spending. Thus, they implicitly refer to other issue dimensions besides redistribution.

2 The size of the sample is reduced significantly because of these variables. Using the same sample, but excluding partisanship and union membership as independent variables, yields a coefficient esti mate of 0.056 (not shown in the table), which is similar to the other models. Hence, the size of the coefficient is reduced because of the inclusion of the partly endogenous variables.

3 In fact, predicted probabilities had to be calculated using a regular logit model with clustered standard errors because the Long/Freese Stata commands commonly used to calculate predicted probabilities do not work after xtlogit.

4 The mean of the dependent variable (support for redistribution) is 0.69 , and the standard deviation is 0.46 .

\section{References}

Alesina, A. and Angeletos, G. M. (2005). Fairness and redistribution. American Economic Review, 95, 960980.

Alesina, A., Glaeser, E. and Sacerdote, B. (2001). Why doesn't the United States have a European style welfare state? Brookings Papers on Economic Activity, 2001, 187278.

Alesina, A. and La Ferrara, E. (2005). Preferences for redistribution in the land of opportunities. Journal of Public Economics, 89, 897931.

Allmendinger, J. and Leibfried, S. (2003). Education and the welfare state: Germany's poverty and plenty and the many worlds of 'competence distribution' in the EC and the OECD. Journal of European Social Policy, 13, 6381 .

Andreß, H. J. and Heien, T. (2001). Four Worlds of Welfare State Attitudes? A Comparison of Germany, Norway, and the United States. European Sociological Review, 17, 337356.

Ansell, B. W. (2008). University challenges: explaining institutional change in higher education. World Politics, 60, 189230.

Ansell, B. W. (2010). The Ballot to the Blackboard: The Redistributive Political Economy of Education. Cambridge: Cambridge University Press.

Armingeon, K. et al. (2010). Comparative Political Data Set 1960 2008. Institute of Political Science, University of Berne.

Arts, W. and Gelissen, J. (2001). Welfare states, solidarity and justice principles: does the type really matter? Acta Sociologica, 44, 283299.

Bean, C. and Papadakis, E. (1998). A comparison of mass attitudes towards the welfare state in different institutional regimes, 1985 1990. International Journal of Public Opinion Research, 10, 211236. 
Becker, G. S. (1993). Human Capital: A Theoretical and Empirical Analysis with Special Reference to Education. Chicago, London: University of Chicago Press.

Blekesaune, M. and Quadagno, J. (2003). Public attitudes toward welfare state policies: a comparative analysis of 24 countries. European Sociological Review, 19, 415427.

Brooks, C. and Manza, J. (2006). Social policy respon siveness in developed democracies. American Sociological Review, 71, 474494.

Brooks, C. and Manza, J. (2007). Why Welfare States Persist: The Importance of Public Opinion in Democracies. Chicago: University of Chicago.

Busemeyer, M. R. (2007). The determinants of public education spending in 21 OECD democracies, 1980 2001. Journal of European Public Policy, 14, 582610.

Busemeyer, M. R. (2009). Social democrats and the new partisan politics of public investment in education. Journal of European Public Policy, 16, 107126.

Busemeyer, M. R., Goerres, A. and Weschle, S. (2009). Attitudes towards redistributive spending in an era of demographic ageing: the rival pressures from age and income in 14 OECD countries. Journal of European Social Policy, 19, 195212.

Busemeyer, M. R. and Nikolai, R. (2010). Education. In Obinger, H. et al. (Eds.) The Oxford Handbook of the Welfare State. Oxford, NY: Oxford University Press, pp. 494508.

Castles, F. G. (Ed.), (2007). The Disappearing State? Retrenchment Realities in an Age of Globalisation. Cheltenham, Northampton: Edward Elgar.

Corneo, G. and Gruner, H. P. (2002). Individual preferences for political redistribution. Journal of Public Economics, 83, 83107.

Cusack, T., Iversen, T. and Rehm, P. (2006). Risks at work: the demand and supply sides of government redistribution. Oxford Review of Economic Policy, 22, 365389.

De La, O. A. L. and Rodden, J. A. (2008). Does religion distract the poor? Income and issue voting around the world. Comparative Political Studies, 41, 437476.

Estévez Abe, M., Iversen, T. and Soskice, D. (2001). Social Protection and the Formation of Skills: A Reinterpretation of the Welfare State. In Hall, P. A. and Soskice, D. (Eds.), Varieties of Capitalism: The Institutional Foundations of Comparative Advantage. Oxford, NY: Oxford University Press, pp. 145183.

Finseraas, H. (2009). Income inequality and demand for redistribution: a multilevel analysis of European public opinion. Scandinavian Political Studies, 32, 94119.

Fong, C. (2001). Social preferences, self interest, and the demand for redistribution. Journal of Public Economics, 82, 225246.
Hasenfeld, Y. and Rafferty, J. A. (1989). The determin ants of public attitudes toward the welfare state. Social Forces, 67, 10271048.

Heidenheimer, A. J. (1997). Disparate Ladders: Why School and University Policies Differ in Germany, Japan, and Switzerland. New Brunswick, London: Transaction Publishers.

Iversen, T. and Soskice, D. (2001). An asset theory of social policy preferences. American Political Science Review, 95, 875893.

Iversen, T. and Stephens, J. D. (2008). Partisan politics, the welfare state, and three worlds of human capital formation. Comparative Political Studies, 41, 600637.

Jaeger, M. M. (2006). Welfare regimes and attitudes towards redistribution: the regime hypothesis re visited. European Sociological Review, 22, 157170.

Jaeger, M. M. (2009). United but divided: welfare re gimes and the level and variance in public support for redistribution. European Sociological Review, 25, 723737.

Jakobsen, T. G. (2010). Public versus private: the conditional effect of state policy and institutional trust on mass opinion. European Sociological Review, 26, 307318 .

Jensen, C. (2011). Capitalist systems, de industrialization, and the politics of public educa tion. Comparative Political Studies, 44, 412435.

Jo, N. K. (2011). Between the cultural foundations of welfare and welfare attitudes: the possibility of an in between level conception of culture for the cultural analysis of the welfare. Journal of European Social Policy, 21, 519.

Kangas, O. (1997). Self interest and the common good: the impact of norms, selfishness and context in social policy opinions. Journal of Socio Economics, 26, 475494.

Kenworthy, L. (2009). The effect of public opinion on social policy generosity. Socio Economic Review, 7, 727740 .

Klitgaard, M. B. (2008). School vouchers and the new politics of the welfare state. Governance, 21, 479498.

Linos, K. and West, M. (2003). Self interest, social beliefs, and attitudes to redistribution: re addresing the issue of cross national variation. European Sociological Review, 19, 393409.

Lipsmeyer, C. S. and Nordstrom, T. (2003). East versus west: comparing political attitudes and welfare pref erences across European societies. Journal of European Public Policy, 10, 339364.

Lynch, J. and Myrskyla, M. (2009). Always the third Rail? Pension income and policy preferences in European democracies. Comparative Political Studies, 42, 10681097. 
March, J. G. and Olsen, J. P. (1989). Rediscovering Institutions. New York: Free Press.

Meltzer, A. H. and Richard, S. F. (1981). A rational theory of the size of government. Journal of Political Economy, 89, 914927.

Moene, K. O. and Wallerstein, M. (2001). Inequality, social insurance, and redistribution. American Political Science Review, 95, 859874.

Moene, K. O. and Wallerstein, M. (2003). Earnings inequality and welfare spending: a disaggregated analysis. World Politics, 55, 485516.

OECD (2009). Education at a Glance 2009: OECD Indicators. Paris: Organisation for Economic Co Operation and Development.

Papadakis, E. (1993). Class interests, class politics and welfare state regimes. British Journal of Sociology, 44, 249270.

Pfau Effinger, B. (2005). Culture and welfare state policies: reflections on a complex interrelation. Journal of Social Policy, 34, 320.

Pierson, P. (1994). Dismantling the Welfare State? Reagan, Thatcher, and the Politics of Retrenchment. Cambridge: Cambridge University Press.

Rehm, P. (2009). Risk and redistribution: an individual level analysis. Comparative Political Studies, 42, 855881.

Rehm, P. (2011). Social policy by popular demand. World Politics, 63, 271299.

Rothstein, B. (1998). Just Institutions Matter: The Moral and Political Logic of the Universal Welfare State. Cambridge: Cambridge University Press.
Scheve, K. and Stasavage, D. (2006). Religion and preferences for social insurance. Quarterly Journal of Political Science, 1, 255286.

Solt, F. (2009). Standardizing the world income inequal ity database. Social Science Quarterly, 90, 231242.

Svallfors, S. (1997). Worlds of welfare and attitudes to redistribution: a comparison of eight western nations. European Sociological Review, 13, 283304.

Svallfors, S. (2004). Class, attitudes and the welfare state: Sweden in comparative perspective. Social Policy \& Administration, 38, 119138.

Svallfors, S. (2010). Policy feedback, generational re placement, and attitudes to state intervention: Eastern and Western Germany, 19902006. European Political Science Review, 2, 119135.

Van Oorschot, W. (2006). Making the difference in Europe: deservingness perceptions among citizens of European welfare states. Journal of European Social Policy, 16, 2342.

Van Oorschot, W., Opielka, M. and Pfau Effinger, B. (Eds.), (2008). Culture and Welfare State: Values and Social Policy in Comparative Perspective. Cheltenham: Edward Elgar.

Wolf, F. (2009). The division of labour in education funding: a cross national comparison of public and private education expenditure in 28 OECD countries. Acta Politica, 44, 5073.

Wolf, F. and Zohlnhofer, R. (2009). Investing in human capital? The determinants of private education expenditure in 26 OECD countries. Journal of European Social Policy, 19, 230244. 